\title{
DPPH Radical Scavenging Activity and Composition of Essential Oil from the Herbs of Jeju Agastache rugosa
}

\author{
Young-Gun Moon, Joon-Seok Hong and Min-Ho Song*
}

\section{HAEIRAE Co., Ltd, Jeju 690-121, Korea}

Received August 4, 2011 /Revised December 14, 2011 /Accepted February 2, 2012

\begin{abstract}
The essential oil obtained by steam distillation of the herbs of Jeju Agastache rugosa has shown significant DPPH radical scavenging activity. For the elucidation of its volatile components, the essential oil was analyzed by GC-MS. Each component was identified by GC or mass spectral analysis. The compounds identified were as follows: pulegone, L-menthone, DL-limonene, isopulegone, beta-caryophyllene, beta-myrcene, and estragole. Several abundant components with phenylpropanoid-type structures may have contributed to the activity. The results suggest that the essential oil may be suitable for development as a food preservative and alternative antioxidant.
\end{abstract}

Key words : Agastache rugosa, essential oil, DPPH, food preservative, antioxidant

\section{서 론}

허브(방향성 식물)는 잎, 꽃, 뿌리, 줄기, 열매 등에서 독 특한 향과 맛이 있어 향신료와 항산화제 등으로 많이 사용 되어 왔으며, 최근에는 건강 보조제, 화장품 등의 기능성 위 주로 이용량이 계속 증가하고 있다. 특히 허브산업은 최근 로하스와 더불어 국내시장에서 고부가가치 전략산업으로 전망되어 식용, 약용, 관상용 등으로 널리 이용되고 있다[4]. 허브산업 중 도입허브를 이용한 건강보조 제품 및 미용관련 제품들은 여러 형태로 출시되고 있지만, 국내에서 재배하는 자생허브를 이용한 제품화 연구는 아직 미약한 수준이다. 국내 허브산업 발전을 위한 관상용, 분화형태, 식용자원화, 허브제품 등 다각적인 접근이 필요하다. 허브는 기능성과 효능이 알려지면서 식용 및 화장품용, 입욕제 등으로 널리 이용되는데, 배초향, 로즈마리 등은 향신료, 샐러드, 오일, 비빔밥 재료 등으로 이용되며, 로즈마리, 라벤더, 페퍼민트 등을 비롯한 도입허브와 배초향, 감국, 구절초, 작약 등의 자 생허브는 주로 화장품용으로 이용된다.

본 연구에서 사용한 배초향(排草香, Agastache rugosa)은 꿀 풀과 (Labiatae)에 속하는 다년초로서 착생 후 군락을 이루고 척박한 산야에서도 생장력이 강하다. 또한, 지리적으로는 동 북아에 분포하고 있으며 우리나라에서는 주로 남부 지방에 야생하거나 일부 재배되고 있는 토착 식용자원이다. 민간에서 는 배초향의 잎을 추어탕이나 각종 찌개, 전병을 부칠 때 고명 등의 향신재료로서 오래 전부터 사용하고 있으며, 꽃은 밀원 (蜜源)으로도 활용되고 있다. 그리고 한방에서는 지상부를 곽 향(蕉香)이라 하여 수독종(水毒腫), 거악기(去惡氣), 지곽란(止

*Corresponding author

Tel : +82-64-759-5789, Fax : +82-64-751-8188

E-mail : frsong@hanmail.net
蕉亂), 요풍(療風), 치비위토역(治肥胃吐逆)에 중요한 약재로 사용하고 있다. 또한, 지하부는 곽향근(蕉香根)이라고 하여 구 토(嘔吐), 하리(下痢), 혈기통(血氣通), 곽란(蕉亂) 등의 치료에 이용되며 곽향을 증류하여 얻은 정유성분은 곽향로(蕉香露)라 고 하여 서열(暑熱)에 의한 흥번(胸煩), 오심(亞心), 기체(氣) 등의 치료에 사용한다. 이와 같이 배초향은 식물 전체 부위를 식용 또는 약용으로 이미 사용하고 있어, 앞으로 널리 활용할 수 있는 농산자원이라 할 수 있다[2].

배초향에 대한 국내외 연구는 diterpene류, flavonoid류, triterpene류, monoterpene 및 sesquiterpene과 더불어 flavonoid 성분에 관한 연구가 이루어져 있다[7,8,13]. 이들 화합 물 중 monoterpene 성분으로는 a-pinene, a-camphene, a -limonene 및 inalool이[3], sesquiterpene 성분으로는 a-ylangene, caryophyllene, calamene이 보고되었으며[6], agastachin, acacetin, tilianin 등의 flavonoid 성분이 알려졌다[6,7]. 또, 배초향의 지하부로부터는 diterpenoid와 triterpenoid에 속하는 수종의 성분들이 분리되었으며[7,8], 특히 Lee 등[10]은 신규물질로서 agastaquinone성분을 분리하여 강한 세포독성 을 보고하였을 뿐만 아니라 rosmarinic acid의 항보체효과도 보고하였으며[18], Min 등[16]은 HIV- 1 protease에 대한 agastaquinone의 억제효과를 보고하였다. 뿐만 아니라, 조직배양 을 통한 정유성분의 생산[19], 안토시안 색소 생성에 관한 유전 형 질 분석 연구[5], 배초향 추출물의 항산화 활성에 관한 연구 [9] 등이 보고 된 바 있다. 식품자원으로서의 이용가능성을 살 펴본 식품학적 연구는 지방산조성[17], 휘발성 성분[2] 및 향기 [1]에 관한 연구보고가 있다. Charles 등[3]과 Wilson 등[21]은 Agastache 속 식물의 종간잡종간과 변이종의 정유 성분이 그 조성과 함량에서 큰 차이를 나타낸다고 보고하였다.

배초향에 존재하는 생리활성 물질에 관한 연구로는 곽향 지하부로부터 diterpene 화합물들이 분리 동전된 바 있고 
[7,13], 잎에서는 강력한 항산화 활성을 지닌 rosmarinic acid 를 함유하고 있음이 밝혀졌다[18]. 또한 곽향의 정유성분에 관 한 연구로서 Charles 등[3]은 미국에서 재배한 배초향의 정유 성분을 조사한 결과 잎에서의 정유 함량은 $1.53 ~ 2.73 \%$ 범위이 고 정유의 주요 구성성분은 methylchavicol이라 보고한 바 있 고 Wilson 등[21]은 역시 미국산 배초향을 사용하여 headspace법으로 분리한 향기성분을 분석한 결과 methylchavicol 과 limonene이 주요 구성성분이라 보고한 바 있다.

한편 Ahn 등[1]은 국내산 배초향으로부터 휘발성 향기성분 을 연구한 바 있고 Lee 등[15]은 국내산 배초향을 사용하여 부위별, 수확시기별 정유함량을 조사하여 8월 중순부터 9월 초에 수확할 경우에는 잎에서의 정유 함량이 높으나 9월 중순 이후에는 잎보다는 꽃에서의 정유함량이 높다고 보고하였다. 또한 Lee 등[5]은 국내산 배초향의 잎과 꽃에서 분리한 정유로 부터 60여 종의 성분을 동정하여 역시 주요성분은 methylchavicol이라고 보고한 바 있다. 또한 배초향의 정유 함량은 잎 $0.23 \%$, 꽃 $0.38 \%$, 줄기 $0.0 \%$ 순으로 상대적으로 꽃에 정유 함량이 많다고 하였다.

본 연구는 제주산 배초향과 국내산 배초향의 지상부에서 추출한 정유 성분에 대하여 비교 분석하였으며, 또한 DPPH radical 소거활성을 측정하여 배초향에 정유 성분의 활용성을 높이기 위한 기초 자료를 제공하고자 수행하였다.

\section{재료 및 방법}

\section{재료}

실험에 사용된 배초향(Agastache rugosa)은 2010년 7 8월 제 주도 성산읍에서 재배되는 배초향과 전라남도와 경상북도에 서 재배되는 배초향은 (쥐뿌리제약에서 구매하여 지상부만을 채취하여 흐르는 물을 이용하여 불순물을 제거한 후 자연건조 과정을 거친 후 실험에 사용하였다.

\section{정유성분의 추출}

시료용기가 51 의 용량으로 고안된 수증기 증류장치에 각각 의 시료 약 $500 \mathrm{~g}$ 씩을 넣고 수증기 발생장치를 이용하여 증류 하였다. 추출용매는 3 차 증류수를 사용하였으며 열원장비로
는 $2 \mathrm{KW}$ 용량의 전기 heatingmantle를 사용하여 약 2시간 동안 리비히 냉각기를 따라 흐르는 증류물을 수집하였다. 수 집된 증류물을 분획깔때기에서 정유와 증류수의 층을 확인 한 후 3회 분획하여 증류수를 제외한 상층액인 정유만을 수집 하여 실험에 이용하였다. 최종 추출된 정유의 양은 추출 종료 후 1 시간동안 충분히 냉각시킨 다음 추출장치에 부착된 게이 지로 측정하였다. 추출된 정유의 수율은 다음의 공식에 의해 서 계산하였다.

Yield of essential oil $(\%)=\frac{\text { Volume of essential oil }(\mathrm{mL})}{\operatorname{Dry} \text { sample }(\mathrm{g})} \times 100$

\section{정유성분 $\mathrm{GC}-\mathrm{MS}$ 분석}

추출된 정유를 gas chromatography와 mass spectrometer 가 부착된 GC-MS를 이용하여 Table 1에 나타낸 바와 같은 조건 하에서 분석하였다. 이 연구에서 정유 성분 분석 목적은 각 화합물의 농도 개념의 정량적 분석이 아닌 채집된 3 종의 시료들(제주산 배초향, 전남 및 경북산 배초향)간의 정유성분 화합물의 조성을 비교하기 하기 위한 것으로 GC-MS분석 후 각 화합물의 peak의 면적으로 화합물의 조성을 상대 비교하였 다. 표준품으로 사용된 isomenthone, anethole, vanillin, eugenol, emthyleugenol은 Sigma사에서 구입하여 사용하였다.

\section{$\mathrm{DPPH}$ 라디칼 소거활성 측정}

추출된 정유의 전자 공여능(electron donating ability, $\mathrm{EDA}$ ) 측정은 Blois의 방법에 준하여(참고문헌) 각각의 정유 DPPH (1,1-diphenyl-2-picryl hydrazyl)에 대한 수소공여 효 과로 측정하였다. 일정농도의 시료와 대조군으로 호주산 Tea tree oil (Puchon, Korea), Ascorbic acid (Sigma, USA), Butylated hydroxyanisole (BHA), butylated hydroxytoluene (BHT)를 사용하여 96-well plate에 $160 \mu 1$ 를 넣고 $0.15 \mathrm{mM}$ $\mathrm{DPPH} 40 \mu 1$ 를 첨가하여 vortex로 균일하게 혼합한 다음 실온 의 암실에서 30 분간 방치한 후, Multi-detection microplate로 $517 \mathrm{~nm}$ 에서 흡광도를 측정하였다. 흡광도를 측정할 때 웰에 분주되는 각 시료에 의한 흡광도의 차이는 ethanol만의 흡광 도를 측정하여 보정해 주었고, 이때 전자 공여능은 시료첨가 구와 비첨가구의 흡광도 차이를 백분율 $(\%)$ 로 구하였으며, 또

Table 1. Condition of GC-MS for the analysis of the essential oil from A rugosa

\begin{tabular}{lll}
\hline & Model & Varian GC-3400 \\
GC & Column & SE-54 (Alltech); $0.32 \mathrm{id} \times 30 \mathrm{~m}$ length; film thickness $0.25 \mu \mathrm{m}$ \\
& Temperture & Injector, detector, transfer line: $250^{\circ} \mathrm{C}$ \\
& Oven program & Initial $80^{\circ} \mathrm{C}$ (hold time, $2 \mathrm{~min}$ ); rate $17^{\circ} \mathrm{C} / \mathrm{min}$; final $250^{\circ} \mathrm{C}($ hold time, $2 \mathrm{~min})$ \\
& Carrier & He, $3 \mathrm{~mL} / \mathrm{min}$ \\
\hline & Model & Finnigan Mat TSQ-700 Quadrupole type (Q1 single stsge MS spectroscopy) \\
& Electron ionization & $70 \mathrm{eV}$ \\
MS & Scan range & LMR $35-600 \mathrm{amu} ;$ rate $0.56 / \mathrm{sec}$ \\
& Temperature & Ion source 150 \\
& Dynode & $-15.0 \mathrm{kV}$ \\
\hline
\end{tabular}


한 배초향 정유 및 대조구의 $\mathrm{EDA}(\%)$ 값을 $50 \%$ 감소시키는 $\mathrm{RC} 50(\mu \mathrm{l} / \mathrm{ml})$ 을 구하였고 모든 실험은 3회 반복 측정하였다.

\section{결과 및 고찰}

\section{배초향 정유성분의 조성}

배초향은 꿀풀과에 속하는 다년생(多年生) 초본(草本)로서 한국을 포함한 일본, 중국, 만주, 동시베리아 지역등에 분포하 고 있으며 국내의 경우도 제주도를 포함한 전국 각지에 널리 분포하고 있다. 독특한 향기와 향미를 지닌 식물성 천연 정유 는 향수, 향신료 및 의약품 등 매우 광범위하고 다양한 산업분 야에서 이용되고 있다. 최근 천연 정유 연구동향은 정유의 기 능적 연구로서 면역성 증가, 신경계 안정효과, 항암효과, 노화 억제 및 피부 병균에 대한 항균력 등의 약리적 특성이 실험적 증거와 함께 보고됨에 따라 천연 정유를 산업적으로 응용하려 는 연구가 증가하고 있다.

한편 배초향의 정유 성분에 관한 연구로서 Fujita [22] 일본 산 배초향의 지상부를 수증기로 증류하여 얻어진 정유에서 주성분으로 methyl chavicol 이외에도 a-pinene, $\beta$-pinene, limonene, $a$-terpinene 등의 monoterpene류와 $\beta$-caryophyllene, $\beta$-humulene, $\beta$-farnesene 등 다수의 sesquiterpene 화합물을 확인한바 있으나 다른 식물에 비교하면 정유성분 조성에 관해서 그다지 연구되지 않은 편이며, 특히 국내산 배 초향의 정유 성분 조성에 대해서는 거의 연구가 되어있지 않 은 실정이다.

본 연구에서는 제주산 배초향의 한의약 자원 연구와 관련하 여 전남산 배초향과 경북산 배초향 지상부에서 정유성분을 분리 한 다음 성분조성을 분석하여 그 차이점을 확인하였다. 본 연구과제에서 각각의 배초향 시료의 지상부를 수증기
증류법을 사용하여 얻어진 정유의 수율은 Table 2에서와 같이 제주산 배초향은 $2.15 \%$, 전남산 배초향은 $1.5 \%$, 경북산 배초향 은 $1.45 \%$ 로서 정유의 함량면에서 Lee 등[14]에 연구결과보다 높은 함량을 나타내었고 제주산 배초향이 타 지역 배초향보다 많은 정유를 함유하고 있다는 것을 본 연구에서 확인 할 수가 있었다.

또한 세 지역에서 재배 되어지는 배초향의 정유성분을 추출 한 후 GC-MS 분석을 통해 정유성분의 조성을 비교하였다 (Table 3).

분석결과 3 종의 배초향 시료 정유에서 14 종의 peak를 확인 하였으며 그 중 9종의 화합물명을 확인하였으며 미량으로 검 출된 5 종의 화합물은 동정을 하지 못하였다. 화합물이 확인된 9종의 성분 중 주요 성분은 limonene, menthone, estragole, pulegone, eugenol methyl ester 등 5종으로 확인되었다. 제주 산 배초향의 주요 정유는 mentone과 pulegone이었으며, 전남 산 배초향 정유의 주요성분은 estragole이었으며, 현재 국내에 한약재로 널리 사용되는 경북지역의 재배종 배초향은 estragole, eugenol methyl ester로 확인되었다. limonene의 경우는 3 종의 시료 각각에서 비슷한 조성비를 보이는 것으로 분석되 었다. 앞서 언급한 정유 성분에 대한 참고문헌들에서는 배초 향의 주요 정유성분 중 estragole 함량이 $90 \%$ 이상이라고 언급 하고 있으나 제주산 배초향의 주요 정유 성분은 mentone과 pulegone이 $67.59 \%$ 를 차지하고 있으며 estragole 성분은 $0.59 \%$ 로 아주 미미하게 나타났다.

식물의 정유는 차광정도와 유기물의 종류 등 재배환경에

Table 2. Essential oil content $(\% / g)$ of $A$. rugosa

\begin{tabular}{cccc}
\hline Arear & Jeju & Jeon-nam & Gyeong-buk \\
\hline Content $(\%)$ & 2.15 & 1.5 & 1.45 \\
\hline
\end{tabular}

Table 3. Composition of the essential oil obtained from the herbs of A. rugosa

\begin{tabular}{|c|c|c|c|c|c|c|}
\hline \multirow{2}{*}{ Compound } & \multicolumn{2}{|c|}{ Jeju } & \multicolumn{2}{|c|}{ Jeon-nam } & \multicolumn{2}{|c|}{ Gyeong-buk } \\
\hline & R.t. $t^{1)}$ & Peak area $\%$ & R.t & Peak area $\%$ & R.t & Peak area $\%$ \\
\hline beta- Myrcene & 9.3 & 0.94 & 9.2 & 0.15 & 9.2 & 0.91 \\
\hline DL-Limonene & 10.8 & 10.34 & 10.8 & 10.53 & 10.8 & 10.04 \\
\hline $\mathrm{N}-\mathrm{C}^{2)}$ & - & - & 13.8 & 1.02 & 13.7 & 0.94 \\
\hline $\mathrm{N}-\mathrm{C}$ & 15.3 & 0.59 & - & - & & \\
\hline D-menthone & - & - & 16.1 & 1.08 & 16.0 & 0.8 \\
\hline L-menthone & 16.4 & 19.47 & 16.4 & 3.6 & 16.4 & 3.48 \\
\hline Isopulegone & 16.9 & 3.81 & - & - & - & - \\
\hline Estragole & 17.9 & 0.59 & 17.9 & 67.25 & 18.1 & 26.99 \\
\hline Pulegone & 20.0 & 48.12 & 19.7 & 2.25 & 19.6 & 1.18 \\
\hline $\mathrm{N}-\mathrm{C}$ & 21.7 & 0.34 & - & - & - & \\
\hline $\mathrm{N}-\mathrm{C}$ & - & - & 23.5 & 0.49 & - & - \\
\hline $\mathrm{N}-\mathrm{C}$ & 23.9 & 0.82 & - & - & - & - \\
\hline Eugenol methyl esther & - & - & - & - & 26.8 & 37.047 \\
\hline beta-Caryophyllene & 27.3 & 2.98 & 27.3 & 4.29 & 27.3 & 3.41 \\
\hline
\end{tabular}

${ }^{1)}$ R.t, Retention time(min); ${ }^{2)} \mathrm{N}-\mathrm{C}$, unknown 
Table 4. DPPH free radical-scavenging activities of $A$. rugosa essential oil and references

\begin{tabular}{cccccccc}
\hline \multirow{2}{*}{ Con. } & \multicolumn{7}{c}{ DPPH scavenging activity $(\%)$} \\
\cline { 2 - 8 } & Ascorbic acid & BHA & BHT & Tea tree oil & Jeju & Jeon-nam & Gyeong-buk \\
\hline $5 \mu \mathrm{g} / \mathrm{ml}$ & $96.5 \pm 2.31$ & $70.3 \pm 7.57$ & $20.2 \pm 0.92$ & - & - & - & $13.6 \pm 0.53$ \\
$1 \%{ }^{1)}$ & - & - & - & $18.5 \pm 0.29$ & $15.6 \pm 0.22$ & $10.5 \pm 0.82$ & 13.21 .03 \\
$2 \%$ & - & - & - & $34.6 \pm 1.12$ & $33.1 \pm 0.59$ & $21.4 \pm 1.03$ & $28.1 \pm 0.29$ \\
$4 \%$ & - & - & - & $58.9 \pm 1.10$ & $58.0 \pm 1.05$ & $34.6 \pm 1.12$ & $42.0 \pm 1.05$ \\
$6 \%$ & - & - & - & $63.7 \pm 2.07$ & $65.1 \pm 1.24$ & $51.2 \pm 1.24$ & $56.1 \pm 1.14$ \\
$8 \%$ & - & - & - & $83.7 \pm 2.12$ & $84.0 \pm 2.02$ & $73.1 \pm 1.89$ & $79.1 \pm 1.89$ \\
$10 \%$ & - & - & - & $92.2 \pm 2.24$ & $91.6 \pm 2.14$ & $84.3 \pm 2.04$ & $87.3 \pm 2.39$ \\
\hline
\end{tabular}

${ }^{1)}$ Essential oil was diluted in methanol to $1 \%, 2 \%, 4 \%, 6 \%, 8 \%, 10 \%$ and the reference were used at $5 \mu \mathrm{g} / \mathrm{ml}$ for DPPH.

따라 함량 및 조성에 차이를 보인다고 한다[10]. 따라서 타 지 역에서 재배되는 배초향 보다 제주에서 재배되고 있는 배초향 의 정유 함량이나 조성면에서 우수하다는 것을 판단 할 수가 있다.

Sun 등[20]에 의하면 국내 향료 시장규모는 약 1,000 억원 대에 이르나 국내 향료 산업은 기술낙후, 투자부족, 고가의 원료수급 등으로 경쟁력이 떨어지고 있어 국내에서만 자생 하는 방향성 식물 또는 국산의 우수성 혹은 특이성이 있는 식물등을 소재로한 향료 개발이 이루어져야 할 필요가 있다 고 하였다.

그러므로 본 연구결과에서도 나타났듯이 제주산 배초향을 한의약 자원으로 뿐만 아니라 향료자원 또는 향장품 자원으로 개발한다면 국내뿐만 아니라 세계적으로도 충분한 경쟁력을 가질 수 있다고 사료된다.

\section{DPPH free radical scavenging activity}

항산화제는 산화로 인한 여러 가지 바람직하지 않은 화합물 의 형성을 방지하기 위해 지질 시스템 내에 첨가된다. 산화에 의해 생성되는 각종 산화 생성물은 DNA를 손상시키거나 암 을 유발하며 인간의 노화와도 관계가 있는 것으로 알려져 있 다[2].

일반적으로 페놀계 합성 항산화제로 널리 사용되고 있는 BHA (butylated hydroxy anisol)와 BHT (butylatedhydroxy toluene)는 그 효과와 경제성 그리고 안정성 때문에 많이 사용 해 왔지만, 합성 식품첨가물의 일반적인 기피 현상뿐만 아니 라 과량 섭취 시 간, 위장점막, 폐, 신장, 순환계 등에 심각한 독성 작용을 일으키는 것으로 알려져 안전한 대체 항산화제의 개발이 요구되었다. 따라서 인체에 무해하고 항산화력이 우수 한 천연 항산화제에 관한 연구가 오래전부터 진행되어 왔으 며, 지금까지 보고된 대부분의 천연 항산화제는 식물 유래이 다. 식물로부터 유래된 페놀물질의 항산화제는 일부가 금속 복합체를 형성하는 작용을 하나, 주요 기능은 이들의 항산화 활성에 있다. 따라서 식물추출물로부터 radical 소거 기능을 탐색함으로써 천연 항산화제를 개발할 수 있다.

본 연구에서는 제주산과 전남 및 경북산 배초향 정유를 호
Table $5 . \mathrm{RC}_{50}$ values of the $A$. rugosa essential oil and reference antioxidants

\begin{tabular}{lc}
\hline \multirow{2}{*}{ Sample $^{\text {b) }}$} & RC50 value $(\%)^{\text {a) }}$ \\
\cline { 2 - 2 } & DPPH scavenging \\
\hline Ascorbic acid $(\mu \mathrm{g} / \mathrm{ml})$ & $2.2 \pm 0.13$ \\
BHA $(\mu \mathrm{g} / \mathrm{ml})$ & $4.7 \pm 0.60$ \\
BHT $(\mu \mathrm{g} / \mathrm{ml})$ & $39.3 \pm 1.11$ \\
Tea tree oil & $3.1 \pm 0.29$ \\
Jeju & $3.2 \pm 0.28$ \\
Jeon-nam & $5.4 \pm 0.72$ \\
Gyeong-buk & $4.8 \pm 0.65$ \\
\hline
\end{tabular}

${ }^{a}$ Concentration required for $50 \%$ reduction of DPPH.

${ }^{b)}$ Values are mean \pm SEM $(n=3)$.

주산 Tea tree oil과 천연 항산화제 ascorbic acid 그리고 합성 항산화제인 BHA, BHT를 사용하여 DPPH radical 소거활성을 비교 분석하였다(Table 4). 또한 각 시료의 RC50을 확인하였다 (Table 5). 대조군으로 $5 \mathrm{\mu g} / \mathrm{ml}$ 농도로 DPPH radical 소거활 성을 측정한 ascorbic acid, BHA, BHT는 각각 $96.5 \%, 70.3 \%$, $20.2 \%$ 의 활성을 나타내고 있으며, 대조군으로 사용한 천연 oil 중 가장 상업적으로 성공한 호주산 Tea tree oil은 $1 \%, 2 \%$, $4 \%, 6 \%, 8 \%, 10 \%$ 농도에서 $18.5 \%, 34.6 \%, 58.9 \%, 63.7 \%, 83.7 \%$, $92.2 \%$ 로 $10 \%$ 농도에서는 천연 항산화제인 ascorbic acid와 유 사한 높은 항산화 활성을 나타내었다.

본 연구에서 분석하려고 하는 제주산, 전남산, 경북산 배초 향 정유의 DPPH radical 소거활성 같은 경우도 시료 농도 의 존적으로 DPPH radical 소거활성이 증가함을 확인할 수가 있 는데 제주산 배초향 정유 같은 경우는 전남산이나 경북산 보 다 높은 DPPH radical 소거활성 $(15.6 \%, 33.1 \%, 58.0 \%, 65.1 \%$, $84.0 \%, 91.6 \%)$ 나타내고 있으며 Tea tree oil 및 Ascorbic acid 와도 유사한 활성을 나타내었다. 그리고 배초향 정유를 포함 한 대조군의 RC50 값을 확인한 결과(Table 5) 천연 항산화제인 Ascorbic acid는 $2.2 \pm 0.13 \mu \mathrm{g} / \mathrm{ml}$, Tea tree oil은 $3.1 \pm 0.29 \mu \mathrm{g} /$ $\mathrm{ml}$, 제주산 배초향 정유는 $3.2 \pm 0.28 \mu \mathrm{g} / \mathrm{ml}$ 으로 나타났다. 이러 한 결과를 바탕으로, 제주산 배초향 정유를 이용하여 향장품, 식품 및 음료 등과 같은 기능성 바이오 소재로서의 다양한 산업적 응용분야에 널리 응용될 수 있을 것으로 생각된다. 


\section{References}

1. Ahn, B. and C. B. Yan. 1996. Volatile flavour component $\mathrm{s}$ of bangah (Agastache rugosa O. Kuntze)herb. Korean J. Food Sci. Technol. 23, 582-586.

2. Ames, B. N. and R. L. Saul. 1987. Oxidative DNA damage, cancer and aging. Oxygen and human disease. Am Inter. Med 107, 536-539.

3. Charles, D. J., J. E. Simon, and M. P. Widrlechner. 1991. Charaterization of essential oil of Agastache species. J. Agric. Food Chem 39, 1946-1949.

4. Chung, H. J. and K. L. Noh. 2000. Screening of electron donating ability, antibacterial activity and nitrite scavenging effect of some herbal extracts. Korean J. Soc. Food Sci. 16, 372-377.

5. Fuentes-Granados, R. G. and M. P. Widrlechner. 1997. Inheritance of antocyanin production of malate dehydrogenase isozymes in Agastache rugosa (Fisher \& Meyer). Kuntze Hort Sci. 32, 733-734.

6. Fujita, S. and Y. Fujita. 1972. Miscellaneous contributions to the essential oils of the plants from various territories. XXIX. Essential oil of Agastache rugosa O. Kuntze(5). Sesquiterpene hydrocarbons in the oil. Yakugaku Zasshi. 92, 908-909.

7. Han, D. S., Y. C. Kim, S. E. kim, H. S. Ju, and S. J. Byun. 1987. Studies on the diterpene constituent of the root of Agastache rugasa O. Kuntze. Korean J. Pharmacogn. 18, 99-102.

8. Han, D. S. 1987. Triterpenes from the root of Agastache rugosa. Korean J. Pharmacogn. 18, 50-53.

9. Jhee, O. H. and C. B. Yang. 1996. Anoxidative activity of extract from bangah herb. Korean J. Food Sci. Technol. 28, 1157-1163.

10. Kim, S. K., S. C. Lee, G. G. Min, S. P. Lee, and B. S. Choi. 1998. Effects of organic matter applications on essential oil contents and composition in Anthriscus sylvestylis Hoffm. Korean J. Medicinal Crop Sci. 6, 16-20.
11. Kim, T. J. 1996. Korean Resources Plants. pp. 44, Publishing center of Seoul National University, Seoul.

12. Lee, H. K., S. R. Oh, J. I. Kim, J. W. Kim, and C. O. Lee. 1995. Agastaquinone, a new cytotoxic diterpenoid quinone from Agastache rugosa. J. Nat. Prod 58, 1718-1721.

13. Lee, H. Y., S. J. Byon, S. R. OH, J. I. Kim, Y. H. Kim, and C. O. Lee. 1987. Diterpenoids from the root s of Agastache rugosa and their cytotoxic activities. Korean J . Pharmacogn. 25, 319-327.

14. Lee, J. C., Y. H. Choi, and Y. H. Kim. 1994. Essential oil in aerial part of Agastache rugosa O. Kuntz. Korean J. Medicinial Crop Sci. 2, 168-173.

15. Lee, S. W., J. B. Kim., K. S. Kim, and M. S. Kim. 1999. Change of growth characteristics rosmarinic acid and essential oil content according to harvest time in Agastache rugosa O. Kuntze. Korean J. Medicinal Crop Sci. 7, 83-88.

16. Min, B. S., M. Hattori, H. K. Lee, and Y. H. Kim. 1999. Inhibitory constituent $\mathrm{s}$ against HIV-1 protease from Agastache rugosa. Arch Pharm Res. 22, 75-77.

17. Nguyen, X. D., D. C. Luu, H. T. Nguyen, D. M. La, V. H. Le, and P. A. Leclercq. 1996. Constituent s of the leaf and flower oils of Agastache rugosa (fisher \& Meyer ) Kuntze from Vietnam. J. Essent. Oil Res. 8, 135-138.

18. Oh, S. R., K. Y. Jung, and H. K. Lee. 1996. In vitro anticomplementary activity of phenylpropanoids from Agastache rugosa. Korean J. Pharmcogn. 27, 20-25.

19. Shin, S. H., H. K. Kim, and H. J. Chi. 1991. Production of giant hyssop oil by plant tissue culture. Korean J. Pharmacogn. 22, 91-94.

20. Sun, S. W. and K. S. Byun. 1997. Application of the Natural Flavor from Plants. Korean J. Corp Sci. 42, 49-57.

21. Wilson, L. A., N. P. Senechal, and M. P. Widerlechner. 1992. Headspace analysis of the volatile oils of Agastache. J. Agric. Food Chem 40, 1362-1366.

22. Fujita, Y. and S. Fujita. 1965. Japanese Chemical Letters, 86, 635.

\section{초록 : 제주산 배초향 지상부에서 얻은 정유의 조성과 항산화 효과 \\ 문영건 · 홍준석 · 송민호 ${ }^{*}$ \\ (주) 해이래)}

수증기증류법으로 얻은 제주산 배초향의 정유는 DPPH radical 소거활성이 현저하게 뛰어나는 것을 확인할 수가 있었다. 제주산 배초향의 유효성분을 확인하기 위해 정유성분을 GC-MS로 분석한 결과 각 성분의 retention time및 mass spectral data의 표준 물질과의 비교에 의해서 Pulegone, L-menthone, DL-limonene, Isopulegone, beta-caryophyllene, beta-myrcene, estragole. 등의 정유성분이 확인되었다. 이 연구에서 밝혀진 여러 성분들은 천 연유기합성물로 항산화 활성이 잘 알려져 있어 이들이 그 유효성분으로 추측된다. 연구결과 제주산 배초향 정유 는 식품 보존제 및 항산화 대체 물질로 개발이 적합하다. 